\title{
Determinants of Nordic entrepreneurship: A reverse engineered pitch
}

\author{
Ondřej Dvouletýa, 1 \\ a University of Economics, Prague, The Czech Republic
}

\begin{abstract}
A bstract: Faff (2015; 2017) has introduced a very useful pitching research template for understanding academic literature and for formation of research ideas and concepts. This pitching research letter (PRL) applies Faff's (2015; 2017) template to the example of a "reverse engineering" pitch in the field of entrepreneurship. I share the positive experience of Salehudin (2017) who applied pitching research template on an al ready published study. In my case, the pitching research template is applied on the article written by Dvoulety (2017), which focuses on the determinants of Nordic entrepreneurship. The letter offers a personal reflection on the application of the pitching research template. Finally, it highlights the need to increase visibility of my own research.
\end{abstract}

Keywords: Pitching Research Letter, Reverse Engineering Pitch, Nordic Entrepreneurship, Necessity Entrepreneurship, Entrepreneurial Economics

J EL codes: M2, M1, L260, Y 20

\section{Introduction}

This pitching research letter (PRL) applies Faff's (2015; 2017) pitching research template to the example of the previously published study by Dvouletý (2017), which focuses on the determinants of Nordic entrepreneurship. The implemented approach conducts a so called "reverse engineering pitch", which was positively experienced by Salehudin (2017) or by Wallin and Spry (2016). Scholars nowadays more frequently use the pitching research template to conceptualize their research and to articulate the main elements of their research intentions. The pitching

1 Corresponding authors: Department of Entrepreneurship, Faculty of Business Administration, University of Economics, Prague; W. Churchill Sq. 4, 13067 Prague 3; the Czech Republic; tel. (+420) 728431 027; email address: ondrej.dvoulety@vsecz 
research template is a good tool not only for masters and doctoral students, but al so for all researchers (Ashraf \& Manzoor, 2017 or Brenner, 2016).

Professor Faff introduced me to this useful tool, during the $\mathrm{PhD}$ seminar series, which took place at the University of Economics, Prague in April 2017. After his workshops, I took a chance to think of my own doctoral research and as a result I have created a reverse engineering pitch which is being introduced in this letter. The novelty of this letter lies in the fact that I have applied the pitching research template to my own research, Dvouletý (2017), which is already published in an academic joumal. The template was applied 6 months after the manuscript was accepted for publication and therefore I could benefit from not only thinking of my own research retrospectively, but also how to share my findings with the key stakehol ders.

In this letter, I firstly describe my step by step approach for creating a reverse engineer pitch. Secondly, I reflect my own personal experience when applying the template and the last section concludes the letter.

\section{Step by step approach}

Before I started with the pitch, I had read Professor Faff's most recent version of the "pitching research" paper (Faff, 2017), and I was thinking about the added value of the pitching research template. As for the second step, I went back to the final version of my recently published article entitled "Determinants of Nordic Entrepreneurship" which was published in the Journal of Small Business and Enterprise Development in 2017. After careful reading of both articles, I thought that writing a pitch could be quite easy, since I already knew all of the key information. However, I was wrong. I spent more than 10 hours of intensive work on the pitching research and I really carefully thought of the added value and novelty of my study with respect to the individual elements of the pitch. For writing of the pitch, I have used the online platform PitchMyResearch.com, which I found to be very intuitive and easy to use. The completed pitch is presented in Table 1. Since I have created a reverse engineering pitch, I have followed the approach described by Salehudin (2017) and entered into section (A) an original name of the published article as a title I must admit that, according to Faff's (2017) expectations, the pitch was completed in a "non-linear" way. For each of the pitch's part, I have returned to the published paper and tried to think of, what was my original intention and how would I approach the part today. Section (B) identifies the main research question "What are the determinants of entrepreneurial activity in the Nordic countries?" 
All three main papers which are depicted in section (C), Freytag and Thurik (2007), Hjorth (2008) and Roig-Tiemo et al. (2015), were authored by gurus in the field of entrepreneurship and they are in the line with the article's main contribution. Motivation/Puzzle (D), tries to identify the research gap and potential for the academic contribution. Despite the fact, that determinants of entrepreneurial activity have been al ready many times studied by entrepreneurship scholars, there is a credible reason, why the determinants could affect entrepreneurial activity in the group of Nordic countries (Denmark, Finland, Iceland, Norway and Sweden) differently. Sections (E), (F) and (G) follow Faff's (2015) "IDioTs" guide and describe the elaborated idea, sources of the data and empi rical approach.

Parts $(\mathrm{H})$ and $(\mathrm{I})$ address the novelty and importance of the presented study. Published academic article contributes to the topic of the determinants of Nordic entrepreneurship from the quantitative perspective, since the previously published studies analyse Nordic entrepreneurship mainly by the qualitative research methods. The study contributes also to the topic of the determinants of entrepreneurship, because the role of some universally-valid drivers of entrepreneurship (eg. $R \& D$ sector) have not been confirmed in the study. Additionally, Nordic policy makers should continue in the reduction of the administrative barriers of entrepreneurship and they should support entrepreneurial endeavours especially during the times of high unemployment Forthcoming research should according to Dvouletý (2017) deeply analyse the outcomes of $R \& D$, innovative and technology policies in the Nordic region, since no positive outcomes have been observed in the study. The novelty of the study was also demonstrated on the Mickey Mouse Diagram which is depicted on Figure 1. Contribution $(\mathrm{J})$ and other considerations $(\mathrm{K})$ inspired me to pitch my research to the relevant stakehol ders and I find this section very important.

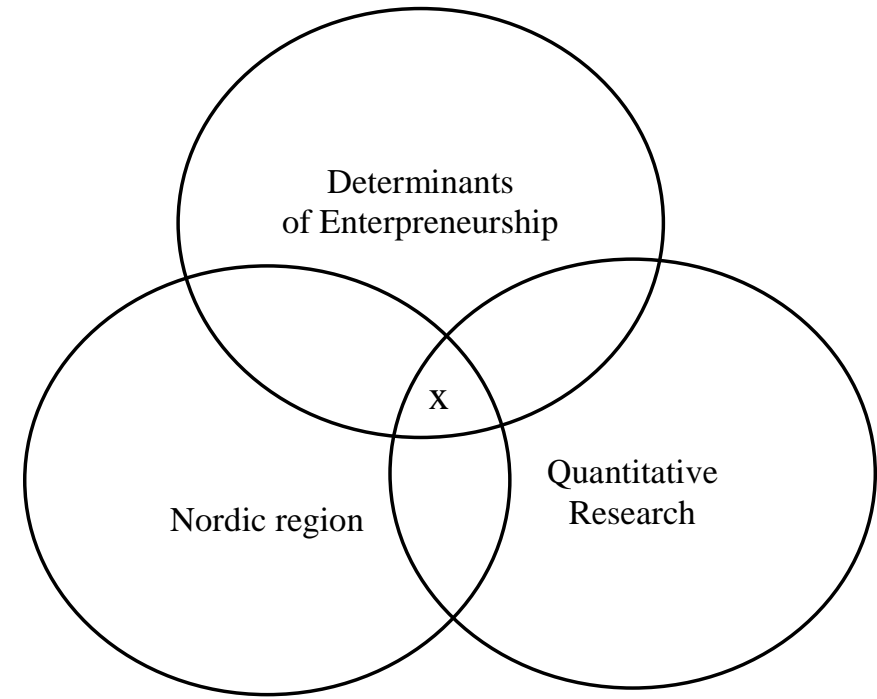

Figure 1: M ickey M ouse Diagram C haracterizing Novelty of the Research 
Table 2. C ompleted reverse engineered pitch template on Dvouletý (2017)

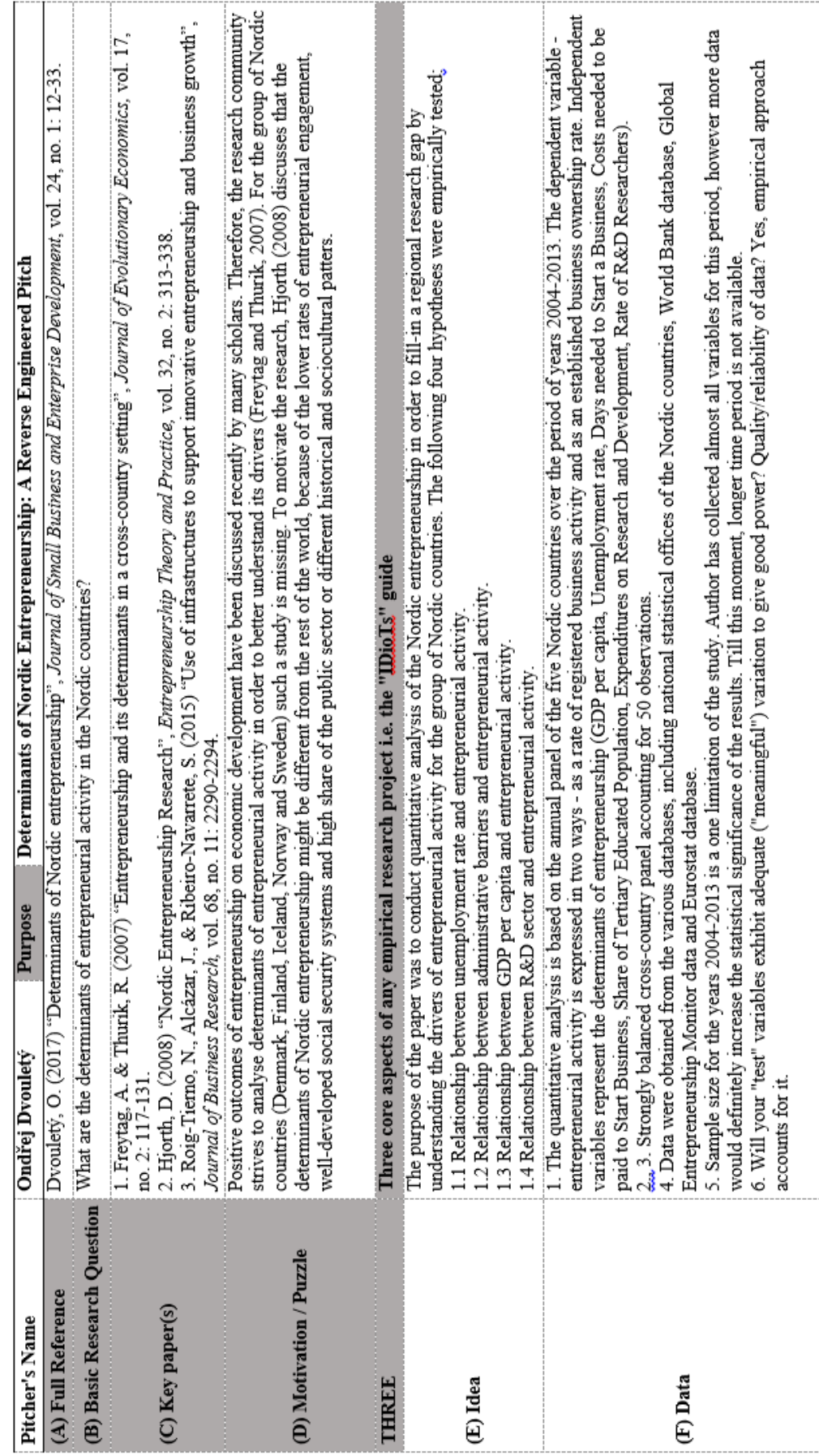

Vol. 16, No. 3 


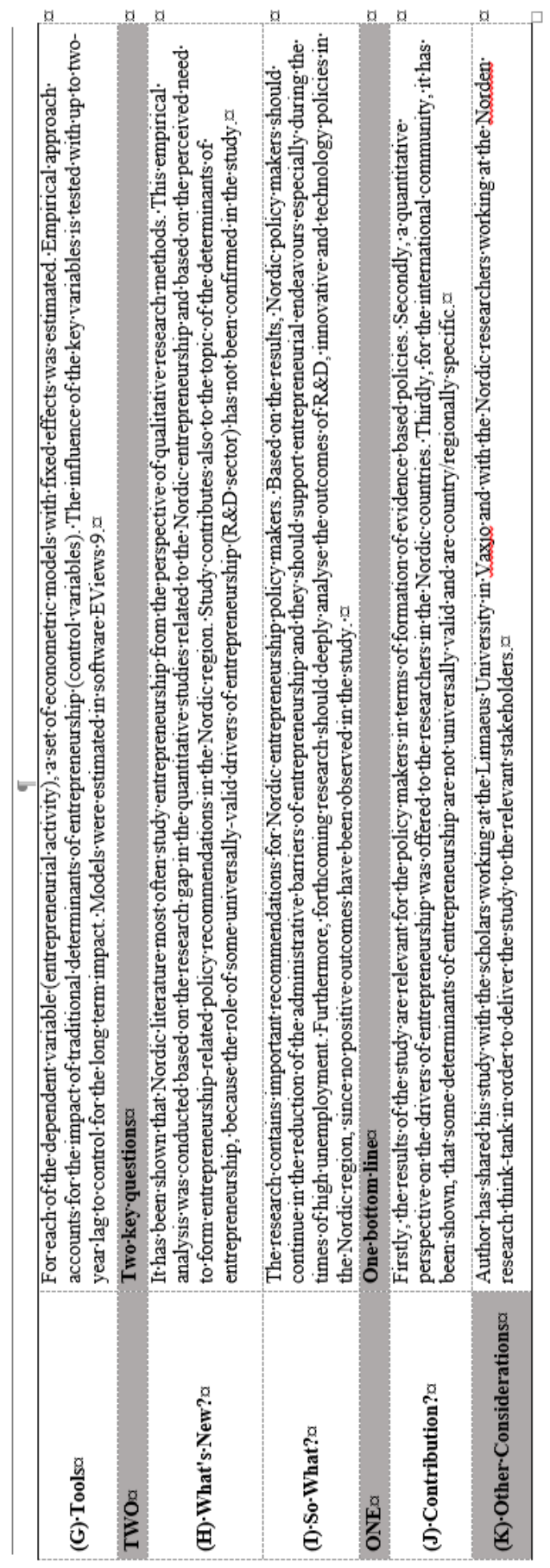

Source: PitchMyResearch.com(2017), own elaboration 


\section{Personal reflection on the reverse-engineering pitch exercise}

After completing the research pitch I felt that this approach provides me a very useful insight into categories of the paper which are the most important. It also led me to think more about the feasibility of the intended study. From the reverse engineering perspective, I feel that the suggested approach could be very useful for conducting a systematic literature review of empirical studies. However, there were two main implications for my own day-to-day research practice.

Firstly, I have realized, how important is to pitch my own research, despite the fact that it has been already published. Every day, there are many articles, which are being published and it is a task of a good researcher to find the most relevant once After completing my study on the determinants of Nordic entrepreneurship, I felt that I have contributed to the regional body of knowledge. However, after finishing the research pitch, I have identified the key stakehol ders and their email addresses and I have distributed them my paper di rectly. From some of them, I have received a positive feedback on my study.

Secondly, I have understood how useful could be the template not only for me, but also for bachelor and master students. At the University of Economic in Prague, PhD students often lead student's theses. I could really save a lot of time, by asking my students to access and read Faff (2017), go into PitchMyResearch.com and to let them think carefully about their own research intentions, before coming to my office.

\section{Conclusions}

In this reverse engineering pitching research letter (PRL) I have applied Faff's $(2015,2017)$ pitching research template on the example of the previously published study by Dvoulety (2017), which was focused on the determinants of Nordic entrepreneurship. I have shared my personal experience with the template and joined scholars from other fields (e g. Sal ehudin, 2017 or Wallin \& Spry, 2016) who implemented the template into their research lives. Based on my personal experience I would encourage other researchers to think of their research ideas in a nuanced and structured way. Finally, pitching research template led me to think more of the need to increase visibility of my own research. 


\section{Acknowledgements}

This work was supported by Internal Grant Agency of Faculty of Business Administration, University of Economics in Prague, under no.: IP300040. The author also expresses his thanks to Robert Faff for demonstrating this useful tool during the seminar series, which took a place at the University of Economics, Prague in April 2017.

\section{References}

Ashraf, H. A. \& Manzoor, N. (2017) "An examination of customer loyalty and customer participation in the service recovery process in the Pakistani hotel industry: A pitch", Accounting and Management Information Systems, vol. 16, no. 1: 199-202

Brenner, M. (2016) "Investigating chef-leader behaviour impacts on subordinate work team identification: A pitch", Accounting and Management Information Systems, vol. 15, no. 4: 826-834

Dvouletý, O. (2017) "Determinants of Nordic entrepreneurship", J ournal of Small Business and Enterprise Devel opment, vol. 24, no. 1: 12-33

Faff, R. W. (2015) "A simple template for pitching research", Accounting \& Finance, vol. 55, no. 2: 311-336

Faff, R.W. (2017) "Pitching Research $\circledR^{\circ}$ ", https://ssrn.com/abstract=2462059 or http://dx.doi.org/10.2139/ssrn.2462059 (on-line access: May 15 $5^{\text {th }}$ 2017)

Freytag, A. \& Thurik, R. (2007) "Entrepreneurship and its determinants in a crosscountry setting", J ournal of Evolutionary Economics, vol. 17, no. 2: 117-131

Hjorth, D. (2008) "Nordic Entrepreneurship Research", Entrepreneurship Theory and Practice, vol. 32, no. 2: 313-338

PitchMyResearch.com (2017), https://pitchmyresearch.com/ (on-line access: May $15^{\text {th }}$ 2017)

Roig-Tiemo, N., Alcázar, J. \& Ribeiro-Navarrete, S. (2015) “Use of infrastructures to support innovative entrepreneurship and business growth", Journal of Business Research, vol. 68, no. 11: 2290-2294

Sal ehudin, I. (2017) "'Reverse engineering' the pitching research template: a simple tool to help understand the academic literature", Accounting and Management Information Systems, vol. 16, no. 1: 203-210

Wallin, A. \& Spry, A. (2016) "The role of corporate versus product brand dominance in brand portfolio overlap: A Pitch", Accounting and Management I nformation Systems, vol. 15, no. 2: 434-439 